\title{
FINTECH, FINANCIAL INCLUSION, AND SUSTAINABILITY: A QUANTITATIVE APPROACH OF MUSLIMS SMES
}

\author{
Yulfan Arif Nurohman ${ }^{1 *}$, Melia Kusuma ${ }^{2}$, Devi Narulitasari ${ }^{3}$ \\ *Corresponding Author \\ ${ }^{1}$ Faculty of Islamic Economics and Business, Institut Agama Islam Negeri Surakarta, Jalan Pandawa, Dusun IV, Pucangan, \\ Sukoharjo, Indonesia, yulfanan@gmail.com \\ ${ }^{2}$ Faculty of Islamic Economics and Business, Institut Agama Islam Negeri Surakarta, Jalan Pandawa, Dusun IV, Pucangan, \\ Sukoharjo, Indonesia, melia.dosen@gmail.com \\ ${ }^{3}$ Faculty of Islamic Economics and Business, Institut Agama Islam Negeri Surakarta, Jalan Pandawa, Dusun IV, Pucangan, \\ Sukoharjo, Indonesia, devina_ede@yahoo.com
}

\begin{abstract}
Sustainability of Small and Medium Enterprises (SMEs) is very important to be noted or observed. Due the majority of Indonesia's population is Muslim and many of them are SMEs Actors. This study aim to provide empiric proves about the relation among financial technology (Fintech), financial inclusion, and sustainability muslims SMEs in Solo Raya area. This study uses quantitative approach. Analysis instrument used in this study is Partial Least Square (PLS). All data in the study are collected by handing out questionnaires to 96 SMEs owners who are Muslim chosen with accidental sampling technique. The result of this study shows that there is a positive relation between financial technology and financial inclusion. Financial technology also have positive relation toward the sustainability of SMEs. Besides that, financial inclusion also have positive relation with the sustainability of SME. With these results, it is expected that could give more viewpoint to the Government to give a convenient access and support the existence and sustainability of SMEs.
\end{abstract}

Keywords: Fintech, financial inclusion, business sustainability, Muslims SMEs

Received Revised Accepted Published

March 24, $2021 \quad$ March 27, $2021 \quad$ March 31, $2021 \quad$ March 31, 2021

\section{INTRODUCTION}

Small and Medium Enterprise (SME) plays a big role in Indonesia's economy, based on business quantity, job creation, or national economic growth which is measured with Gross Domestic Product (Ananda \& Susilowati, 2018). The majority of Indonesia's population is Muslim and many of them are SMEs Actors. Islam clearly support commerce and trade by becoming an entrepreneur through Al Quran (the Holy Book for Muslims). Islamic entrepreneurship is doing business through innovation or risk but still following some of the guidelines set in the Al-Quran namely by prohibiting dishonesty, greed, exploitation, monopoly, uncertainty, interest, and transacting prohibited (haram) goods and services.

Behind its vital role, Muslims SMEs face many challenges. It is recorded that 60 to $70 \%$ of Muslims SMEs have not get funding access yet. Funding is a classic problem that hinder the growth of SMEs because they could not develop innovation and increase their production (Rizal et al., 2019). In addition, Muslim entrepreneur must also obtain funding sources that in accordance with sharia law. When this problem is not solved then it will disturb the sustainability of muslims SMEs and the bigger impact causing economy decrease in Indonesia.

Sustainability is SMEs capability to keep the business running continuously. According to (Eresia-Eke \& Raath, 2013b), SMEs that have business sustainability are the SMEs that 
have increasing growth from time to time. Three things that can be measured to find the sustainability of SMEs are financial capability, strategic capability, and organizational capability. One of the way to improve sustainability in financial capability is through financial inclusion (Le et al., 2019).

The Director of Financial Literacy and Education of The Financial Services Authority (OJK), Horas VM Tanihoran, states that financial inclusion index in Indonesia is relatively low. Financial understanding about SMEs could help in managing and accessing financial product. Financial inclusion defined as process that ensures the ease of access, availability, and usage of the formal financial system for all members of an economy (Sarma, 2012b). Convenient banking access is expected to build asset and help SMEs activity. Financial inclusion is expected to increase the standard of living completely in the society (DemirgucKunt et al., 2015). (Aribawa (2016) and (Wise (2013) find that financial inclusion influences the performance and sustainability of SMEs.

One of the obstacles to increase Indonesia's financial inclusion index is the access to formal financial institution were low because of the lack of knowledge and product complexity offered by financial institution (Nugroho \& Purwanti, 2018). This is supported by a survey of national financial literacy conducted by The Financial Services Authority (OJK) in 2013 to 2016, there is improvement of financial inclusion index, from $59.7 \%$ to $67.8 \%$ in 2016 (Otoritas Jasa Keuangan, 2017). But that numbers are still out of target. Therefore, the government target the improvement of financial inclusion index as much as $75 \%$. The target is with Government Regulation (PP) No. 502017 about National Strategy for Consumer Protection and Government Regulation (PP) No.82 2016 about National Strategy for inclusive finance (Tempo, 22/2/19).

Every region has different index level. This disparity shows the difference in economic condition and individual characteristic of every region (Nugroho \& Purwanti, 2018). Special Capital Region of Jakarta is the province that has the most massive index of national financial inclusion. Other provinces are yet to show the consistency of financial inclusion index. Central Java occupy 21st position on financial inclusion index (Otoritas Jasa Keuangan, 2017).

To support and extend financial inclusion there is a platform that develop information technology that is Fintech or Financial Techology (Makina, 2019). Fintech is a technologybased business that competes or collaborates with financial institution (Rusydiana, 2019). In another definition, (Lee \& Teo, 2015) states that Fintech refers to financial service or innovative product that is delivered by new technology. Based on Hutabarat's study (2018), it is found that information technology product influences financial inclusion in Jabodetabek community. Another study by Fitriani, (2018) and Sari \& Dwilita (2018)) shows that Fintech able to increase financial inclusion. Besides that, financial inclusion increase through banking digitalization that integrate with Fintech evidently has positive effect in that financial inclusion (Mittal et al., 2016).

Alaabed \& Mirakhor (2017) have examined the role of Fintech in accelerating the implementation of Islamic financial risk sharing. They argue that Fintech is closer to sharia principles because it can eliminate two main risks in banking, namely immaturity and leverage. The growth of customers and revenue of Fintech companies that comply with sharia 
is quite bright, especially in Muslim countries because people feel safe using products that are in accordance with sharia principles.

In this digital era, technology have crucial in developing SMEs especially those owned by Muslims so it can compete with other products. Nika Pranata the winner Call for Submission IDF 2019 mentions that to improve the competitiveness of SMEs it needs a boost to go digital and go online (Jawa Pos, January 16th 2020). Fintech can decrease asymmetric information and increase the supply of bank credit SMEs (Sheng, 2020).

Financial Technology or Fintech refer to technology usage to produce financial solution (D. Arner et al., 2016) and could decrease funding obstacle toward SMEs (Makina, 2019). The convenience offered by Fintech have effect in materializing Indonesia's hope as the widest digital country in 2014 (Muzdalifa et al., 2018c). The role of financial technology to strengthen financial inclusion and SME's growth in Indonesia make an easier funding access especially for non-bankable SMEs (Shofawati, 2019). According to Firmansyah \& Anwar (2019) Indonesia with a majority Muslim population is a country that is most ready to become an Islamic Fintech hub in the world. The Financial Services Authority (OJK) noted that there were 3 Islamic peer-to-peer (P2P) lending companies in Indonesia.

Fintech is still a brand new product to muslims SMEs. So it needs collaboration between Fintech and financial institution in order to increase financial inclusion (Fitriani, 2018), while to support the sustainability of SMEs require Fintech usage and improvement of society's financial inclusion. Therefore, it is required to find out the relation among Fintech, financial inclusion, and the effect toward SME's sustainability in Solo Raya.

\section{LITERATURE REVIEW}

\section{Islamic Financial Technology (Fintech)}

Financial Technology or Fintech refers to the use of technology to produce financial solutions (D. W. Arner et al., 2016). This understanding results in three unique observations. First, Fintech is not a new development for the financial industry. The introduction of the telegraph provided the necessary infrastructure for the development of the first period of financial globalization at the end of the 19th century. Second, the financial industry is one of the primary users of information technology services with expenditures of more than $\$ 197$ Billion in 2014 (Lodge et al., 2015). Since the late 80s, finance has become an industry based on digital technology transmission and manipulation, for example, ATM. Third, the term Fintech is not specific to one particular sector, such as financing or peer to peer business but includes all services and products traditionally provided by the financial services industry. Since 2014, this sector has attracted the attention of policymakers, consumers and industry players. Fintech's rapid growth makes it necessary to have regulations because of its role in the industry and financial infrastructure. Fintech is now often seen as a union of financial services and information technology. These two things have always been synergized and strengthened with each other. The global financial crisis in 2008 was the reason for Fintech to develop into a new paradigm. This new evolution poses a challenge for policymakers and market participants on how to balance potential benefits with emerging risks.

OJK has prepared several strategies so that the peer to peer (P2P) fintech industry can increase financial inclusion in the community, especially in the SMEs sector. The first step 
prepared is the preparation of technical regulations related to the implementation of registration, licensing, supervision, and online loan supervision system Fintech. Next is the development of collaboration between the government financial services industry and Fintech loan providers to build and strengthen the digital economic ecosystem. The latter is the development of an ongoing and open dialogue between the government and regulators, Fintech players and associations in order to improve the quality of Fintech loan regulation.

Alaabed \& Mirakhor (2017) and Firmansyah \& Anwar (2019) studied the role of Fintech in reporting Islamic financial risk. financial technology that is closer to the spirit of sharia because it eliminates major risks in the banking industry, namely immaturity and leverage. Fintech is also innovative providing solutions to encourage financial inclusion and solve certain social problems.

Bank Indonesia classifies Fintech into four categories: 1) payment, clearing, settlement; 2) deposits, lending, capital raising (including crowdfunding / peer-to-peer lending); 3) market provisioning; and 4) investment \& risk management.

Crowdfunding talks about mass capital models (for example Investree, KapitalBoost, KitaBisa), while peer-to-peer lending is direct capital without going through intermediaries (e.g. Crowdo, Uang Teman, Dr Rupiah). Market provisioning is a model of market data analysis services (for example, Cek Aja, Halomoney), while risk and investment management is a digital financial management service. Islamic Fintech peer-to-peer (P2P) lending firms in Indonesia is PT Ammana Fintek Syariah (Ammana), PT Dana Syariah Indonesia (Dana Syariah), and PT Investree Radhika Jaya (Investree).

\section{Financial Inclusion}

The World Bank formulates financial inclusion as an easy way for individuals and business units to have access and financial products that are useful and affordable to meet needs responsibly. Financial understanding of SMEs makes it easier to manage and access financial products. Financial inclusion is a process that facilitates access, availability, and benefits of the formal financial system for all economic actors (Sarma, 2012). The Indonesian Financial Services Authority (OJK) defines financial inclusion as all efforts aimed at making all forms of price and non-price barriers to the public's access to use financial services (OJK, 2017).

Access to banking services is an essential part of economic growth. Easily accessible banking services can attract SMEs entrepreneurs in accessing banking, such as borrowing and saving. The ease of banking access is expected to be able to build assets and help MSME activities. Financial inclusion is expected to improve the overall standard of living in the community (Klapper et al., 2012).

The term financial inclusion has been a trend since the 2008 global financial crisis. Based on the impact of the crisis on groups in the bottom of the pyramid (low and irregular income, living in remote areas, disabled people, workers without legal identity documents, and peripheral communities) which are generally unbanked are recorded to be very high outside developed countries. Bank Indonesia defines financial inclusion as all efforts aimed at removing all price and non-price barriers to public access in utilizing financial services. OJK defines financial inclusion as availability of access to various institutions, products, financial 
services by the abilities and needs of the community in order to improve the welfare of the community.

Chen \& Volpe (1998) describe financial literacy into four dimensions. There are a) Personal financial management (personal finance) is the process of financial planning and control of individual or family units. b) The form of savings in the Bank, such as deposit, giro, and savings. c) Insurance is a form of risk management that anticipate unexpected risk by paying an insurance premium. Another definition of insurance is a transfer of risk from the first party to another party. d) Investment is a form of income allocation currently carried out to obtain future benefits that can exceed the investment capital currently being spent.

The objectives of financial inclusion, according to the Financial Services Authority Regulations include increasing public access to PUJK financial institutions, products and services; increasing supply of financial products and / or services by PUJK in accordance with the needs and abilities of the community; the increasing use of financial products and / or services in accordance with the needs and abilities of the community; and the increasing quality of the use of financial products and services according to the needs and abilities of the community.

\section{The sustainability of SMEs}

A company's performance is a reflection of a company's ability to create value, both from a financial and non-financial perspective (Hudson et al., 2001). The financial perspective is the company's ability to improve the welfare of shareholders through the profits generated, while the non-financial perspective is the company's ability to create positive values such as environmental performance, and social responsibility. Thus, the company is said to have excellent performance if both of these performances show the better value, meaning that from a first financial side, but also do not forget the non-financial aspects.

Meanwhile, sustainability is the ability of a company to continue to run a business. According to Eresia-Eke \& Raath (2013), SMEs that have business sustainability are SMEs that always experience growth from time to time. That is, if SMEs experience business stagnation, then it is certain that the SMEs are unable to continue the business.

Performance measurement and sustainability of companies at SMEs have a more straightforward measurement system than companies that have gone public (Kumar \& Jayant, 2017). According to Eresia-Eke \& Raath (2013), several things that need to consider in measuring the performance and sustainability of MSMEs are:

1. Financial capabilities, namely the ability of SMEs to generate profits for their owners.

2. Strategic capabilities, namely the ability of SMEs to make strategic plans that are useful for SMEs, especially those relating to customer relations.

3. Organizational ability, namely the ability of SMEs to form an excellent organizational climate.

These three aspects are the main aspects that must consider in measuring the performance and sustainability of SMEs. 


\section{Hypotheses}

\section{The correlation of Fintech and the financial inclusion}

Fintech is a financial product developed by various financial institutions to facilitate public access to their financial products (Muzdalifa et al., 2018). Economic digitalization has a good impact on financial products because now people can enjoy a variety of financial products in their grasp. The presence of Fintech in the financial world will certainly make access to financial products also easier. Thus, Fintech will make SMEs access to various kinds of financial products also easier. In addition, Fintech that is in accordance with Islamic sharia already exist, so Muslim entrepreneurs will no longer hesitate to use it.

Based on the study of Hutabarat (2018), it found that Fintech products affected financial inclusion in the Jabodetabek community. Based on theoretical reviews and results of previous studies, the first hypothesis in this study is as follows:

H1: There is a positive correlation of Islamic Fintech and financial inclusion

\section{The correlation of Islamic Fintech and the SMEs' sustainability}

As mentioned before, economic digitalization has good impact for SMEs' sustainability. The arrival of financial technology has made the transaction between seller and buyer become easier (Lodge et al., 2015). When using traditional payment, the seller and buyer must meet at the same time and place to complete the transaction, but when using Fintech transaction can be completed while the seller and buyer are apart.

Based on study of Muzdalifa, Rahma, \& Novalia (2018) the arrival of Fintech will make better the financial inclusion for SMEs, thus it will impact on the SME's sustainability. The positive impact also find on the study of Ardiansyah (2019), the find that the Fintech will help the SMEs' problem on equity, thus it will make SMEs sustain. Based on the theoretical framework above, the second hypothesis is as follows:

H2: There is a positive correlation of Fintech and SMEs' sustainability.

\section{The correlation of financial inclusion and the SMEs' sustainability}

Financial inclusion defined as the level of public accessibility to financial products provided by financial institutions (Umar, 2017). Products of financial institutions are needed by SMEs to support the progress of their businesses. Financial technology products will facilitate financial transactions with customers, even get additional capital from digital money lending platforms. Thus, financial inclusion will improve the performance and sustainability of SME businesses.

Based on research by Aribawa (2016) and Wise (2013) found that financial inclusion affects the performance and sustainability of SMEs. Based on theoretical reviews and results of previous studies, the third and fourth hypotheses in this study are as follows:

H4: There is a positive correlation of financial inclusion and the SMEs' sustainability

\section{METHODOLOGY}

This study is conducted to Muslims SMEs in Solo Raya area, that are Sukoharjo, Sragen, Boyolali, Winogiri, Klaten, and Karanganyar regency. Samples on this study are as much as 96 SMEs whose owner must be Muslim chosen by accidental sampling technique. The 
questionnaire on this study consist of two types. First, quiz type and the second is likert type. Quiz type questionnaire used to measure Fintech's construct, while likert type questionnaire used to measure financial inclusion's construct also SME's sustainability.

Table 1. Constructs and Indicators of the study

\begin{tabular}{|c|c|c|}
\hline Construct & Indicator & Measurement \\
\hline $\begin{array}{l}\text { Financial } \\
\text { (Fintech) }\end{array}$ & $\begin{array}{l}\text { 1) Market collectors } \\
\text { 2) Risk Management and Investment } \\
\text { 3) Pengetahuan tentang produk fintech } \\
\text { (Otoritas Jasa Keuangan, 2017) }\end{array}$ & $\begin{array}{l}1 \text { if the answer is and } 0 \text { if } \\
\text { the answer is false. }\end{array}$ \\
\hline Financial Inclusion & $\begin{array}{l}\text { 1) Use of bank account and deposit } \\
\text { 2) Use of insurance product } \\
\text { 3) Use of bank loan } \\
\text { (Otoritas Jasa Keuangan, 2017) }\end{array}$ & $\begin{array}{l}5 \text { if the answer is agree } \\
\text { and } 1 \text { if the answer is } \\
\text { not. }\end{array}$ \\
\hline SMEs Sustainability & $\begin{array}{l}\text { 1) Financial capability } \\
\text { 2) Strategic capability } \\
\text { 3) Organizational capability } \\
\text { (Eresia-Eke \& Raath, 2013) }\end{array}$ & $\begin{array}{l}5 \text { if the answer is agree } \\
\text { and } 1 \text { if the answer is not } \\
\text { agree. }\end{array}$ \\
\hline
\end{tabular}

Source: researcher, designed for the study

Analysis instrument used on the study using Partial Least Square - Structural Equation Modeling (PLS-SEM) with the assistance of SmartPLS application version 3.0 to test the hypothesis. Model developed on the study can be found below:

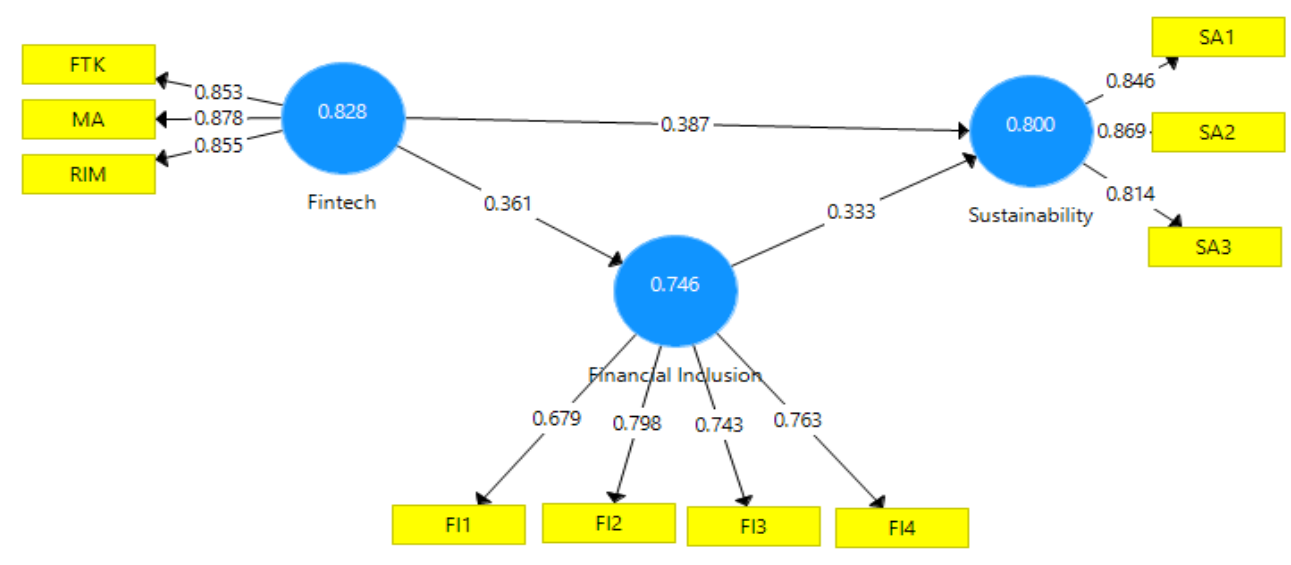

Figure 1. The PLS-SEM Model of Study 


\section{DISCUSSION}

\section{Respondent Characteristic}

The respondents of the study are 96 Muslims SMEs owners, that come from Solo Raya, that are Wonogiri, Sragen, Boyolali, Sukoharjo, Klaten, Karanganyar and Surakarta. Table 2 below is the summary of respondent characteristic on the study:

Table 2. Respondent Characteristics

\begin{tabular}{|c|c|}
\hline Characteristic & Explanation \\
\hline Business Location & $\begin{array}{l}\text { 1. Downtown: } 42 \text { respondents. } \\
\text { 2. Uptown: } 54 \text { respondents. }\end{array}$ \\
\hline Business Age & $\begin{array}{l}\text { 1. Less than } 1 \text { year: } 14 \text { respondents. } \\
\text { 2. 1-5 years: } 46 \text { respondents. } \\
\text { 3. 6-10 years: } 18 \text { respondents. } \\
\text { 4. More than } 10 \text { years: } 18 \text { respondents. }\end{array}$ \\
\hline Gender & $\begin{array}{l}\text { 1. Male: } 52 \text { respondents. } \\
\text { 2. Female: } 44 \text { respondents. }\end{array}$ \\
\hline Respondents' Age & $\begin{array}{l}\text { 1. Below } 20 \text { years old: } 0 \text { respondent. } \\
\text { 2. } 21 \text {-30 years old: } 31 \text { respondents. } \\
\text { 3. } 31-40 \text { years old: } 35 \text { respondents. } \\
\text { 4. } 41-50 \text { years old: } 18 \text { respondents. } \\
\text { 5. More than } 50 \text { years old: } 12 \text { respondents. }\end{array}$ \\
\hline Respondents' Education Background & $\begin{array}{l}\text { 1. Elementary School: } 9 \text { respondents. } \\
\text { 2. Junior High School: } 8 \text { respondents. } \\
\text { 3. Senior High School: } 35 \text { respondents. } \\
\text { 4. Bachelor: } 44 \text { respondents. } \\
\text { 5. Master: } 0 \text { respondent. } \\
\text { 6. Doctor: } 0 \text { respondent. }\end{array}$ \\
\hline Business Income & $\begin{array}{l}\text { 1. Less than } 2 \mathrm{M}: 25 \text { respondents. } \\
\text { 2. } 2 \mathrm{M}-4 \mathrm{M}: 41 \text { respondents. } \\
\text { 3. } 4 \mathrm{M}-6 \mathrm{M}: 17 \text { respondents. } \\
\text { 4. More than } 6 \mathrm{M}: 13 \text { respondents. }\end{array}$ \\
\hline Employee & $\begin{array}{l}\text { 1. No employee: } 39 \text { respondents. } \\
\text { 2. 1-5 employees: } 53 \text { respondents. } \\
\text { 3. 6-10 employees: } 3 \text { respondents. } \\
\text { 4. 11-15 employees: } 0 \text { respondent. } \\
\text { 5. More than } 15 \text { employees: } 1 \text { respondent. }\end{array}$ \\
\hline
\end{tabular}

Source: Researcher's survey, 2019

Table 2 above shows that among 96 respondents, 42 respondents have businesses in the downtown, while 54 respondents have businesses in the uptown. Furthermore, as many as 52 respondents were male, and 44 respondents were female.

In terms of business age, 14 SMEs are less than one-year-old, 46 SMEs aged 1 to 5 years, 18 SMEs aged 6 to 10 years, and 18 SMEs aged more than ten years. Then in terms of educational background, 9 respondents were graduated from elementary school, 8 respondents were graduated from junior high school students, and 35 respondents were graduated from junior high school. 44 respondents completed their education at university, as a bachelor degree. 
Then in terms of the age of the respondents, there were no respondents under the age of 20 years old. Furthermore, there are 31 respondents aged between 21-30 years old, 35 respondents aged between 31-40 years old. Thirty respondents aged more than 40 years old. Furthermore, in terms of income, there are 25 SMEs that have an income of under 2 million Rupiahs per month, 41 SMEs have income between 2 million to 4 million Rupiahs per month, 17 SMEs have income between 4 million to 6 million Rupiahs per month, and 13 SMEs have income of more than 6 million Rupiahs per month. Finally, judging from the number of employees, 39 SMEs are self-managed, 53 respondents have 1 to 5 employees, 3 SMEs have 6 to 10 employees, and 1 SMEs has more than 10 employees.

\section{Measurement Model}

Before testing the hypothesis, we will discuss first about the accuracy of the model. The components used to test the accuracy of the model are outer-loading and composite reliability. Accuracy of the testing results of the model are presented in table 3 below.

In the first stage, all of the constructs are tested, but some constructs do not meet the "rule of thumb" requirements. According to Sofyani (2015), the minimum threshold that can be accepted in each component is 0.6 . There are no loading that have value below 0.7 . So, it can be concluded that the model is fit.

Table 3. Constructs and Indicators

\begin{tabular}{lccc}
\hline \multicolumn{1}{c}{ Constructs } & Loading & Composite Reliability & $\mathbf{R}^{2}$ \\
\hline Fintech & FTK $=>0.853$ & 0.834 & \\
MA $=>0.878$ & & \\
Financial Inclusion & RM $=>0.855$ & 0.879 & \\
& FI1 $=>0.679$ & & \\
& FI2 $=>0.798$ & & \\
Sustainability & FI $=>0.743$ & 0.130 & \\
& FI $=>0.763$ & & \\
& SA1 $=>0.846$ & & \\
SA2 $=>0.869$ & & \\
SA3 $=>0.814$ & & \\
\hline
\end{tabular}

The table above shows that the outer-loading value is in the range of 0.679 to 0.869 . As mentioned before, the threshold that can be tolerated for each component is 0.6. Even so, this study model still has a great Cronbach Alpha that the values are 0.834, 0.839, and 0.881 .

Table 3 shows that the R-Squared values for this model are $13 \%$ and $35.4 \%$. The Fintech variables are only able to explain financial inclusion variables of $13 \%$. The financial inclusion variable is only able to explain the sustainability variable of $35.4 \%$ on the. This $\mathrm{R}$ Squared value is relatively low, so there are still many other variables that need further study.

\section{Hypothesis Testing}

From the results of model testing in the previous step, bootstrapping is then performed to test the significance of the influence between variables. The results of hypothesis testing are presented in table 4 below. 
Table 4. Hypothesis

\begin{tabular}{lcccc}
\hline \multicolumn{1}{c}{ Impact } & Hypotheses & Coefficients & Sign & P-Values \\
\hline Fintech $\rightarrow$ Financial Inclusion & $\mathrm{H}_{1}$ & 0.361 & + & $0.002^{*}$ \\
Fintech $\rightarrow$ Sustainability & $\mathrm{H}_{2}$ & 0.387 & + & $0.000^{*}$ \\
Financial Inclusion $\rightarrow$ Sustainability & $\mathrm{H}_{3}$ & 0.333 & + & $0.000^{*}$ \\
\hline
\end{tabular}

Notes: * significant at $5 \%$

Table 4 shows that the path coefficient between Fintech and the financial inclusion is 0.361 with a p-value of $0.002(<0.05)$, so it can be concluded that the Fintech variable influences financial inclusion. Thus, the first hypothesis in this study was accepted. Table 4 shows that the path coefficient between financial inclusion and sustainability is 0.387 with a p-value of $0.000(<0.05)$, so it can be concluded that the financial inclusion variable influences the performance of SMEs. Thus, the second hypothesis in this study was accepted. Table 4 shows that the path coefficient between financial inclusion and sustainability is 0.333 with a p-value of $0.000(<0.05)$, so it can be concluded that the financial inclusion variable influences the sustainability of SMEs. Thus, the third hypothesis in this study was accepted.

Based on the results of hypothesis testing, it can be seen that from the three hypotheses proposed in this study all of them are accepted.

\section{Fintech Relation on Financial Inclusion}

Result of hypothesis testing shows that Fintech's variables influence the financial inclusion. It shows that Fintech product have succeed to become an alternative for Muslims entrepreneur to get financial inclusion. By the Fintech existence challenges of financial inclusion such as access restriction to formal financial institution, lack of knowledge, and product complexity offered by financial institution can be solved (Nugroho \& Purwanti, 2018) It is in accordance with the Financial Services Authority (OJK) aspiration in National Strategy on Indonesian Financial Literacy (SNLKI) that push Fintech to take a role in providing financial inclusion (Otoritas Jasa Keuangan, 2017).

As we all know, internet and smartphone penetration had penetrate many aspects of life. Both are the Fintech's key of success in providing inclusive finance to society. Moslems can enjoy various financial products within their hands without worrying about sharia principles because of information disclosure. Fintech existence will give convenience and facility for muslims SMEs owner to do financial transaction. They no longer have to come and queue in financial institution to do financial transaction.

Classic problem that often experienced by Muslims SMEs about funding is also can be solved. Fintech gives convenience and easier requirements compared to when applying credit in formal financial institution. An inaccurate knowledge and inaccurate financial management often make SMEs non bankable. Non bankable SMES hardly qualify when applying for fund in formal financial institution. But with all the practicality on getting fund which become a positive point for Fintech so with that convenience society's financial 
inclusion can increase. The result of this study also support the study (Fitriani, 2018; Hutabarat \& Purwanto, 2008; Mittal et al., 2016; Muzdalifa et al., 2018c).

\section{Fintech Relation on SMEs Sustainability}

The results of hypothesis testing, shows that there is significant correlation between financial-technology and SMEs' sustainability. It shows that financial products can support financial performance so SMEs can survive by providing enough equity. All this time SMEs are vulnerable toward the country's economic decline. There is no denying that all of this happened because of their capital is relatively low. The complexity in applying fund often makes SMEs that need fund cannot get that fund. Problems for Muslim entrepreneurs also increase because of the various sharia requirements that must be met so as not to violate the rules in the Islamic Religion So at the end of many SMEs go bankrupt because of that problem.

Besides that, the existence of financial technology can facilitate SMEs' transaction that make their cash flow become better. So far, many SMEs have difficulty in collecting receivables, so the cash flow of the SMEs is not smooth. The presence of virtual money products provided by various platforms has proven to be able to expedite payments, thereby minimizing the existence of receivables. The result of this study prove that Fintech can support the sustainability of SME.

Fintech exist to complete financial institution to give easier access in applying fund (D. Arner et al., 2016; Firdaus et al., 2018; Makina, 2019) This is a very positive sign for SMEs owner, especially for the non-bankable to get a fund (Shofawati, 2019). Besides that financial transaction like purchase of raw material, expenses payment, debts, etc. that is done by SMEs will be easier.

This is in harmony with The National Medium-Term Plan (RPJMN) of 2005 to 2025. On the international stage, especially in South East Asia, the government aim to make Indonesia to become the biggest digital country in South East Asia in 2020. OJK regulation number 77/POJK.01/2016 on Information Technology-Based Lending Services (LPMUBTI) and Bank Indonesia Regulation (PBI) 18/40/PBI/2016 on operation of payment transaction processing (Djawahir, 2018). This convenience will increase the effectiveness and efficiency of SMEs so it is hoped that SMEs will grow from time to time.

\section{Financial Inclusion Relation on SMEs' Sustainability}

The result of this study shows that the third hypothesis of this study is accepted. It shows that there is significant correlation between the financial inclusion and the sustainability of SME. Financial inclusion defined as the level of accessibility of the SME to the financial product. When the financial product is accessible for the community, it indicates the better financial inclusion. The financial inclusion is the fundamental factor to help the SME survive for a long time. When the SME cannot get the financial product, they will be shut down because lack of equity.

The financial products are needed by the SME for their sustainability, especially for providing enough equity to support their operational, so the financial institutions have to ensure that their product are accessible to the SMEs. The arrival of financial technology will make the financial inclusion better, so it can help the SMEs to survive along the time. This 
study is similar to the study of (Aribawa, 2016b; Le et al., 2019; Wise, 2013b) that financial inclusion can increase SMEs' sustainability.

\section{CONCLUSION}

Based on the previous discussion we made, we can conclude some points; there is significant correlation between financial technology and financial inclusion, there is significant correlation between financial technology and SMEs' sustainability, there is significant correlation between financial inclusion and SMEs' sustainability.

With those results it is expected that there will be collaboration and synergy among the managers of Fintech, financial institution, SMEs to increase financial inclusion that can support SMEs' sustainability from Islamic perspective. So the final purpose of increasing Indonesia's economy to make the society prosperous can be achieved. Besides that, this study is expected to give a viewpoint to the government to give a convenient access and support the very existence of business and SMEs' sustainability.

\section{REFERENCES}

Alaabed, A., \& Mirakhor, A. (2017). Accelerating Risk Sharing Finance via FinTech: NextGen Islamic Finance. In The 1st International Colloquium on Islamic banking and Finance (pp. 1-10)

Ananda, A. D., \& Susilowati, D. (2018). PENGEMBANGAN USAHA MIKRO KECIL DAN MENENGAH (UMKM) BERBASIS INDUSTRI KREATIF DI KOTA MALANG. Jurnal Ilmu Ekonomi JIE, 1(1), 120-142.

Aribawa, D. (2016). Pengaruh literasi keuangan terhadap kinerja dan keberlangsungan UMKM di Jawa Tengah. Jurnal Siasat Bisnis, 20(1), 1-13.

Arner, D., Barberis, J., Buckley, R., Law, U., Arner, D. W., \& Buckley, R. P. (2016). THE EVOLUTION OF FINTECH: A NEW POST-CRISIS PARADIGM? (2015/047).

Arner, D. W., Barberis, J. N., \& Buckley, R. P. (2016). The Evolution of Fintech: A New Post-Crisis Paradigm? SSRN Electronic Journal, 47(4), 1271-1319.

Chen, H., \& Volpe, R. P. (1998). An analysis of personal financial literacy among college students. Financial Services Review, 7(2), 107-128.

Demirguc-Kunt, A., Klapper, L., Singer, D., \& Oudheusden, P. van. (2015). The little data book on financial inclusion.

Djawahir, A. U. (2018). Teknologi-Layanan Keuangan, Literasi-Inklusi Keuangan, dan Value pada Fintech Syariah di Indonesia: Perspektif S-O-R (Stimulus-Organism-Response) Model. In Proceedings of Annual Conference for Muslim Scholars, (Series 1) (pp. 439448).

Eresia-Eke, C. E., \& Raath, C. (2013). SMME Owners' financial literacy and business growth. Mediterranean Journal of Social Sciences, 4(13), 397-406.

Firdaus, F., Rif'ih, M. W., \& Maharani, B. (2018). Internet Financial Reporting: Ditektor Eskalasi Pembiayaan Modal Umkm Berbasis Stakeholder Value Sebagai Implementasi Financial Technology. In PROSIDING EKONOMI KREATIF DI ERA DIGITAL 1.1 .

Firmansyah, E. A., \& Anwar, M. (2019). ISLAMIC FINANCIAL TECHNOLOGY (FINTECH): ITS CHALLENGES AND PROSPECT. In Achieving and Sustaining SDGs 2018 Conference: Harnessing the Power of Frontier Technology to Achieve the Sustainable Development Goals (ASSDG 2018) (pp. 52-58). Atlantis Press 
Fitriani, H. (2018). KONTRIBUSI FINTECH DALAM MENINGKATKAN Situs Peer to Peer Lending pada Pertanian di Indonesia). EL BARKA: Journal of Islamic Economics and Business Faculty of Islamic Economics and Business, 01(01), 1-26.

Hudson, M., Smart, A., \& Bourne, M. (2001). Theory and practice in SME performance measurement systems. International Journal of Operations and Production Management, 21(8),

Hutabarat, F. (2018). Pengaruh literasi keuangan dan financial technology terhadap inklusi keuangan pada masyarakat jabodetabek. Institut Pertanian Bogor.

Klapper, Jandu, \& Sintim-Aboyage. (2012). The Little Data Book on Financial Inclusion 2012. In The Little Data Book on Financial Inclusion 2015. International Bank for Reconstruction and Development.

Le, T. H., Chuc, A. T., \& Taghizadeh-Hesary, F. (2019). Financial inclusion and its impact on financial efficiency and sustainability: Empirical evidence from Asia. Borsa Istanbul Review, 19(4), 310-322.

Lee, D. K. C., \& Teo, E. G. S. (2015). Emergence of FinTech and the LASIC Principles Emergence of FinTech and the LASIC Principles Citation Citation Emergence of FinTech and the LASIC Principles 1. Journal of Financial Perspectives, 3(3), 1-26.

Lodge, G., Zhang, H., \& Jegher, J. (2015). IT spending in banking: A global perspective. Londres: CELENT. Obtenido de http://www. celent. com/reports/it-spending-bankingglobal-perspective-2.

Makina, D. (2019). The Potential of FinTech in Enabling Financial Inclusion. In Extending Financial Inclusion in Africa (pp. 299-318). Elsevier.

Mittal, S., Joshi, D., Sue Lin, L., \& Tacchi Art Director, M. (2016). Digital Banking New Avatar-Banks Watch Out for Banks.

Muzdalifa, I., Rahma, I. A., \& Novalia, B. G. (2018a). Peran Fintech Dalam Meningkatkan Keuangan Inklusif Pada UMKM Di Indonesia (Pendekatan Keuangan Syariah). Jurnal Masharif Al-Syariah: Jurnal Ekonomi Dan Perbankan Syariah, 3(1).

Nugroho, A., \& Purwanti, E. Y. (2018). DETERMINAN INKLUSI KEUANGAN DI INDONESIA (GLOBAL FINDEX 2014). Jurnal Dinamika Pembangunan , 1(1), 1-13.

OJK. (2017). Strategi Nasional Literasi Keuangan Indonesia (Revisit 2017). Otoritas Jasa Keuangan, 1-99.

Otoritas Jasa Keuangan. (2017). STRATEGI NASIONAL LITERASI KEUANGAN INDONESIA (Revisit 2017).

Rizal, M., Maulina, E., \& Kostini, N. (2019). FINTECH SEBAGAI SALAH SATU SOLUSI PEMBIAYAAN BAGI UMKM. AdBispreneur, 3(2), 89. https://doi.org/10.24198/adbispreneur.v3i2.17836

Rusydiana, A. (2019). Bagaimana Mengembangkan Industri Fintech Syariah di Indonesia? Pendekatan Interpretive Structural Model (ISM). Al-Muzara'ah, 6(2), 117-128.

Sari, P. B., \& Dwilita, H. (2018). PROSPEK FINANCIAL TECHNOLOGY (FINTECH) DI SUMATERA UTARA DILIHAT DARI SISI LITERASI KEUANGAN, INKLUSI KEUANGAN DAN KEMISKINAN. Kajian Akuntansi, 19(1), 9-128.

Sarma, M. (2012). Index of Financial Inclusion - A measure of financial inclusiveness. In Berlin Working Papers on Money, Finance, Trade and Development.

Sheng, T. (2020). The effect of fintech on banks' credit provision to SMEs: Evidence from China. Finance Research Letters, 39, 101558.

Shofawati, A. (2019). The Role of Digital Finance to Strengthen Financial Inclusion and the Growth of SME in Indonesia. KnE Social Sciences, 3(13).

Sofyani, H. (2015). Modul Praktik Partial Least Square ( PLS ). In Universitas Muhammadiyah Yogyakarta. Universitas Muhammadiyah. 
Wise, S. (2013). The Impact of Financial Literacy on New Venture Survival. International Journal of Business and Management, 8(23), 30-39. 